\title{
Jaburetox: update on a urease-derived peptide
}

\author{
Arlete Beatriz Becker-Ritt ${ }^{*}$, Camila Saretta Portugal ${ }^{1}$ and Célia Regina Carlini ${ }^{2}$
}

\begin{abstract}
Urease from Canavalia ensiformis seeds was the first enzyme ever to be crystallized, in 1926. These proteins, found in plants, bacteria and fungi, present different biological properties including catalytic hydrolysis of urea, and also enzyme-independent activities, such as induction of exocytosis, pro-inflammatory effects, neurotoxicity, antifungal and insecticidal properties. Urease is toxic to insects and fungi per se but part of this toxicity relies on an internal peptide $(\sim 11 \mathrm{kDa})$, which is released upon digestion of the protein by insect enzymes. A recombinant form of this peptide, called jaburetox (JBTX), was constructed using jburell gene as a template. The peptide exhibits liposome disruption properties, and insecticidal and fungicidal activities. Here we review the known biological properties activities of JBTX, and comment on new ones not yet fully characterized. JBTX was able to cause mortality of Aedes aegypti larvae in a feeding assay whereas in a dose as low as of $0.1 \mathrm{\mu g}$ it provoked death of Triatoma infestans bugs. JBTX $\left(10^{-5}-10^{-6} \mathrm{M}\right)$ inhibits the growth of E. coli, P. aeruginosa and B. cereus after $24 \mathrm{~h}$ incubation. Multilamellar liposomes interacting with JBTX undergo reorganization of the membrane's lipids as detected by small angle X-ray scattering (SAXS) studies. Encapsulating JBTX into lipid nanoparticles led to an increase of the peptide's antifungal activity. Transgenic tobacco and sugarcane plants expressing the insecticidal peptide JBTX, showed increased resistance to attack of the insect pests Spodoptera frugiperda, Diatraea saccharalis and Telchin licus licus. Many questions remain unanswered; however, so far, JBTX has shown to be a versatile peptide that can be used against various insect and fungus species, and in new bacterial control strategies.
\end{abstract}

Keywords: Peptide, Bacteria, Membranes, Nanoparticles

\section{Background}

Ureases (urea amidohydrolases; EC 3.5.1.5) are enzymes that catalyze the hydrolysis reaction of urea to ammonia and carbamate, which then decomposes through a spontaneous reaction of carbon dioxide in a second molecule of ammonia. These enzymes have been isolated from a wide variety of organisms including plants, fungi and bacteria $[1,2]$.

The urease extracted from Canavalia ensiformis seeds is one of the landmarks in the study of enzymes. It was the first enzyme to be crystallized, demonstrating that enzymes are proteins [3]. It was also the first one to be identified as a metalloenzyme containing nickel in its active site [4].

\footnotetext{
* Correspondence: arlete.ritt@ulbra.edu.br; arletebeatriz@yahoo.com.br ${ }^{1}$ Graduate Program in Cellular and Molecular Biology Applied to Health, Lutheran University of Brazil (ULBRA), Canoas, RS, Brazil

Full list of author information is available at the end of the article
}

The classical urease, called jack bean urease (JBU), is composed of a polypeptide chain of 840 amino acid residues and has a molecular mass of $90 \mathrm{kDa}$. The minimum active form is a trimer of $270 \mathrm{kDa}$ and it is often found in its native form as a hexamer of $540 \mathrm{kDa}[5,6]$. The second isoform of jack bean urease, canatoxin (CNTX), was isolated from the seed and originally characterized as a neurotoxic protein [7]. It features two chains with a molecular mass of $95 \mathrm{kDa}$ held together by non-covalent bonds, and it has about $40 \%$ of the enzymatic activity of JBU; each subunit contains one zinc atom and one nickel atom [8]. Importantly, despite the high similarity with JBU, this less abundant isoform has lower ureolytic activity [6].

Ureases and derived peptides show several biological activities including membrane disruption and permeabilization, fungicidal and insecticidal properties [9]. Jaburetox2Ec and jaburetox (JBTX) are the two first versions of a recombinant peptide with 91 amino acids, based 
on jack bean urease sequence, with a potent effect against insects, yeasts and filamentous fungi [10-12].

Urease and its derived peptide were evaluated for their action on the diuresis of the bug Rhodnius prolixus through an in vitro assay with Malpighian tubules [13]. It was observed that although both urease and JBTX inhibited diuresis, they recruited distinct signaling cascades. While urease activates the eicosanoid pathways and depends on the transport of calcium ions, JBTX inhibits diuresis by changes in levels of cGMP and in the transmembrane potential [13].

The insecticidal activity of JBTX occurs at very low doses $(0.01$ and $0.1 \% \mathrm{w} / \mathrm{w})$ when compared to other plant derived entomotoxic proteins, regardless of the route of administration, either orally or by injection into the hemocell [12].

Molecular studies of JBTX revealed that the peptide contains a sequence that could adopt a $\beta$-hairpin conformation at its $\mathrm{C}$-terminal region, a structure similar to that found in antimicrobial peptides (AMPs) with membrane rupture properties [10]. To assess the importance of the peptide structure in the biological activities of JBTX, Martinelli et al. [14] conducted molecular studies and site-directed mutagenesis, aiming to identify structural motifs related to the toxic activities.

The mutants derived from jaburetox were called: jaburetox $\mathrm{N}$-terminal, corresponding to residues from 1 to 44 (JBTX N-ter); jaburetox C-terminal, residues from 45 to 93 (JBTX C-ter); and jaburetox- $\Delta \beta$, without the amino acids 61 to 74 (JBTX $\Delta-\beta$ ), which corresponds to the $\beta$-hairpin region. All mutants were tested in different biological assays. In insect toxicity tests, the data suggest that the $\beta$-hairpin region is not important for entomotoxicity and that the N-terminal portion of JBTX is responsible for insecticidal activity. However, the C-terminal region of the peptide, which contains the $\beta$-hairpin moiety, is likely to contribute significantly to the ability of JBTX to interact with a lipid bilayer [12, 14].

The ability of these peptides to form ion channels in lipid bilayers was also confirmed by testing with planar lipid bilayers (PLB) [15]. In this study, it was shown that the peptide, as well as the above mentioned mutants can insert themselves into planar lipid bilayers and form cation selective ion channels. The data obtained by Martinelli et al. [14] brought important contributions to the understanding of the JBTX's mechanism of action, suggesting that it represents a new type of active peptide in membranes, with insecticidal and fungitoxic properties. The antifungal activity of JBTX against yeasts occurs at higher doses $(9$ to $18 \mu \mathrm{M})$ than those observed for JBU $(0.27 \mu \mathrm{M})$, suggesting that other regions of the protein could probably be involved in this activity [11].

The overall conformation of the peptide JBTX was elucidated using techniques such as light scattering, circular dichroism and nuclear magnetic resonance [16]. The authors demonstrated the intrinsically disordered nature of the peptide, which exists in a "pre molten globule" state, and its tendency to form an $\alpha$-helix motif near the $\mathrm{N}$-terminus and two turn-like structures (located in its central/C-terminal polypeptide portions). Thus, although JBTX has low propensity to present secondary structure, and despite being an intrinsically disordered protein, the peptide has some degree of folding [16].

\section{What's New? \\ Can the peptide control disease vectors and insect pest in agriculture?}

The mosquito Aedes aegypti (Diptera: Culicidae) is the vector responsible for transmitting diseases to humans, such as urban yellow fever, dengue and more recently, Chikungunya and Zika viruses [17]. Presently the main form of control of these diseases still is by fighting its vector, which requiers complex and coordinated actions of various sectors of the society as well as changes in population habits [18].

In Brazil, endemic disease fighting agents and national and municipal health agents are working together with the population and are responsible for promoting the chemical mechanical control of the disease vector. The actions are focused on detecting and destroying natural or artificial reservoirs of water that can serve as a deposit for the mosquito's eggs. Educational activities are another strategy postulated by the Ministry of Health including community agents visiting residences, in order to ensure the sustainability of the elimination of breeding sites, in an attempt to break the transmission chain of the disease [17].

In order to test a new mosquito control strategy, the insecticidal activity of lyophilized Escherichia coli cells overexpressing the peptide JBTX against $A$. aegypti larvae was evaluated [19]. Peptide quantification performed by ELISA showed that $E$. coli cells produced about $27 \mu \mathrm{g}$ JBTX per mg of dry matter. For the test, mosquito larvae were feed with fish food containing the recombinant $E$. coli cells to 10 or $100 \mu \mathrm{g}$ of JBTX. As control, E. coli cells without JBTX were used in the same proportion. The survival rate and stage of progression of the biological cycle from pupa to adult were accompanied. A suspension of $E$. coli containing $100 \mu \mathrm{g}$ of JBTX promoted $90 \%$ mortality of $A$. aegypti larvae on the first day and $97.5 \%$ in 6 days Fig. 1 . The results emphasized the entomotoxic potential of JBTX to control $A$. aegypti by interfering in the mosquito biological cycle and producing mortality of larvae as well as adult insects [19].

Triatoma infestans is the main vector of Chagas disease in South American countries and the control of the disease strongly depends on vector eradication [20]. Despite extensive insecticide application, the disease is 


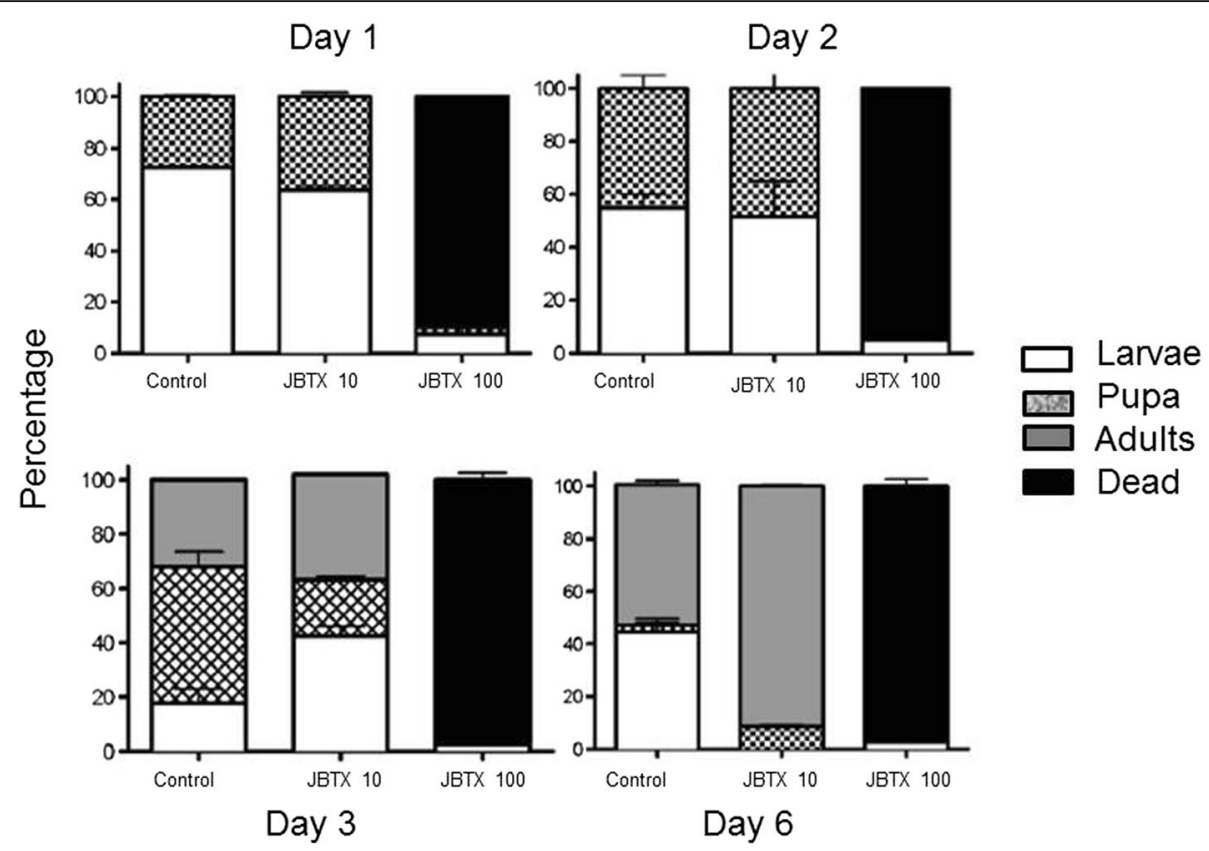

Fig. 1 Effects of jaburetox-V5-loaded lyophilized E. coli on A. aegypti. Mosquito larvae, 25 per experimental condition, were fed fish diet soaked with a suspension of lyophilized E. coli cells containing 0 (control), 10 or $100 \mu \mathrm{g}$ of JBTX, as quantified by ELISA. Controls with non-transformed E. coli were run in parallel. The larvae were kept at $28^{\circ} \mathrm{C}$ with a photoperid of $8: 16$ (light:dark) and developmental stage and mortality were recorded daily up to day 6 . The results are average of duplicates, and expressed as a percentage relative to the initial number of insects. Copyright by K. Kappaun [19]. Reprinted with permission

still endemic in South America [21]. Using T. infestans as a model, Galvani et al. [22] demonstrated that injection of $0.1 \mu \mathrm{g}$ of JBTX/mg of body weight into adults caused death of all insects in less than $24 \mathrm{~h}$. After $3 \mathrm{~h}$ of injection, insects show neurotoxic symptoms such as abnormal behavior of antennae and uncoordinated leg movements, which precede death. JBTX was found to bind to neuronal cells and to interfere with at least two enzymes of the insect brain:

- JBTX strongly inhibited the activity of nitric oxide synthase, thereby reducing the levels of the nitric oxide neurotransmitter;

- JBTX was found to physically interact with and to increase the activity of UDP-N-acetylglucosamine pyrophosphorylase (UDP-GlcNAcP), an enzyme involved in glycosylation pathways and in the synthesis of chitin [22].

In an in vitro study, JBTX also activated UDP-GlcNAcP from the cotton stainer bug Dysdercus peruvianus, an insect that is susceptible to the insecticidal activity of both, urease and JBTX [22, 23].

Rhodnius prolixus, another triatomine vector of Chagas disease in South America, has been extensively used as an insect model in the studies to elucidate the mechanism of action of urease and derived peptides.
Besides interfering with diuresis, crop physiology and causing effects related to the central nervous system (CNS), JBTX was shown to disrupt the immune response of $R$. prolixus, affecting the ability of the insect to effectively counteract bacterial infection [24].

According to the United Nations data, about one billion people are still hungry worldwide [25]. In addition, according to the World Hunger [26], almost all the hungry people are living in developing countries. Globally, every year about $35 \%$ of all crop production is lost to pre-harvest biotic stresses and an additional 6 to $20 \%$ of losses are due to post-harvest events [27]. With an average annual loss of 25 million tons, corresponding to $7.7 \%$ of the Brazilian agricultural production, the financial damage can reach $\$ 16$ billion per year [28].

If we take only into account the sugarcane crop, Brazil is the largest producer in the world. Data from the National Supply Company (Conab) show that in the 2016/ 2017 harvest, the country harvested over 657 million tons of sugarcane with a production of 38 million tons of sugar [29]. The losses that the giant borer, Telchin licus licus, can potentially cause include reduction of $12.1 \%$ in sugarcane production, $4 \%$ loss in sugar production and 3\% reduction in ethanol production. Moreover, annual expenditures on insect control methods allow estimating that the losses caused by this insect can reach $\mathrm{R} \$ 4.88$ billion per year [29]. 
To access the effect of JBTX on the cotton stainer bug Dysdercus peruvianus an insect model that relies on cathepsins as its main digestive enzyme was employed. Third instars insects were fed artificial cottonseeds containing lyophilized $0.01 \%(w / w)$ JBTX. After 10 days, the mortality was two times higher for bugs that fed on freeze-dried purified JBTX than that observed for those that ingested the jackbean urease isoform canatoxin, at the same dose [10,23].

Insects relying on trypsin-like alkaline serine-proteinases as main digestive enzymes, such as the fallworm Spodoptera frugiperda, were shown to be resistant to canatoxin's insecticidal effect. This fact was attributed to the breakdown of canatoxin by the proteolytic enzymes produced by these insects as well as to the lack of production of the entomotoxic peptide. On the other hand, third instar $S$. frugiperda reared on Phaseolus vulgaris foliar discs containing air-dried JBTX were susceptible to the entomotoxic activity of JBTX. These experiments demonstrated that lepidopterans and other insects relying on trypsin-based digestion, although not being able to hydrolyze urease to release its internal peptide, could be targets of the preformed toxic peptide $[10,23]$.

Another example is that of the polyphagous pest Helicoverpa armigera (corn earworm). It was first identified in Brazil during the 2012-2013 crop season, causing serious damage to the production of cotton, soybean, corn, green beans, tomatoes, citrus and pastures. Asia, Europe, Africa, and Australia reports U\$ 2 billion damages caused by $H$. armigera annually, whereas Brazil suffered a damage of approximately U\$ 0.8 billion when it first emerged [30]. Feeding on a few micrograms of JBTX, or its truncated version with deletion of a $\beta$ hairpin, caused mortality and a significant reduction in dietary intake in Helicoverpa armigera caterpillars [14]. When newborn caterpillars were fed on disks of corn leaves containing the peptides, $69 \%$ mortality and a $70 \%$ reduction in consumption were observed (Didoné et al., unpublished data).

\section{Can bacteria be controlled using the peptide?}

Bacteria are responsible for causing heavy agricultural losses and for the vast majority of hospital infections [31]. The USA expends per year about 30 billion dollars dealing with hospital infections, and this amount is expected to increase as more bacteria become drug resistant [31].

Following the method described by Pompilio et al. [32], JBTX - at a wavelength of $620 \mathrm{~nm}$ and turbidimetrically monitored - revealed a bacteriostatic effect against Bacillus cereus, Escherichia coli, Pseudomonas aeruginosa and Staphylococcus. Bacteria were incubated with different concentrations of JBTX (from 0.25 up to $13.5 \mu \mathrm{M})$ added to the growth medium. Their multiplication rate was compared to that in the presence of buffer (Tris $\mathrm{HCl} 10 \mathrm{mM}, \mathrm{pH}$ 7.0) as a negative control and $\mathrm{H}_{2} \mathrm{O}_{2}$ as a positive control. Figure 2 shows a dosedependent inhibitory effect of JBTX on the four bacterial strains. Growth inhibition of $50 \%$ was seen for $E$. coli, $P$. aeruginosa and $B$. cereus with $13.5 \mu \mathrm{M}$ of JBTX after $24 \mathrm{~h}$ of incubation [33]. This inhibitory effect was reversed upon transferring the bacteria to a JBTX-free medium (not shown).

In the context of plant-derived antibacterial peptides, JBTX is as effective as other molecules described in the literature, as summarized in Table 1. Thus fabatins show bacterial activity against gram-negative bacteria in the range of $4-20 \mu \mathrm{M}[34,35]$. Cp thionine- 2 is active at $12-$ $25 \mu \mathrm{M}$ concentration [36]. Hispidalin, from the seeds of Benincasa hispida, at 7- $\mu \mathrm{M}$ concentration demonstrated a broad inhibitory effect against bacteria and caused significant inhibition of the filamentous fungi [37].

The yet preliminary evaluation of the antibacterial activity of JBTX demonstrated its inhibitory activity against bacteria of medical and agricultural importance at doses ranging from $2.25 \mu \mathrm{M}$ (for E. coli) to $6.75 \mu \mathrm{M}$ (B. cereus, $P$. aeruginosa, $S$. aureus). The antibacterial activity of JBTX reinforces previous findings of antimicrobial activity of this plant-derived peptide against fungi and yeast of biomedical importance [11]. Therefore, jaburetox is a promising lead molecule for development of new antibiotics and antifungal drugs (Fig. 2) [33].

\section{Is there any effect on membranes?}

JBTX's ability to interact with lipid membranes has been previously described. Barros et al. [38] observed that JBTX was able to permeabilize acidic liposomes to release entrapped carboxy-fluorescein. Piovesan et al. [15] reported that JBTX, as well as some of its truncated mutants, was capable of inserting itself into neutral planar lipid bilayers forming cation-selective ion channels. More recently, Micheletto et al. [39] studied by small angle X-ray scattering (SAXS) the interaction among JBTX and multilamellar liposomes with a lipid composition typical of human platelets membrane. The interaction among JBTX and the liposomes led to alterations of the Bragg peak, indicating a significant reduction of the lamellar repeat distance and in the number of lamellar repeats. The data suggested that, besides not causing lysis of the vesicles, JBTX promoted a reduction in the size of the liposomes probably due to reorganization of the membrane lipids in the presence of the peptide. A reduction of the Caille parameter indicated that the liposome membrane became more rigid, which altered the peptide insertion into the lipid membrane.

Interestingly, jack bean urease (JBU), from which JBTX is derived, showed similar behavior towards platelet-like multilamellar liposomes. Since the JBU internal sequence corresponding to JBTX is well exposed at the protein 


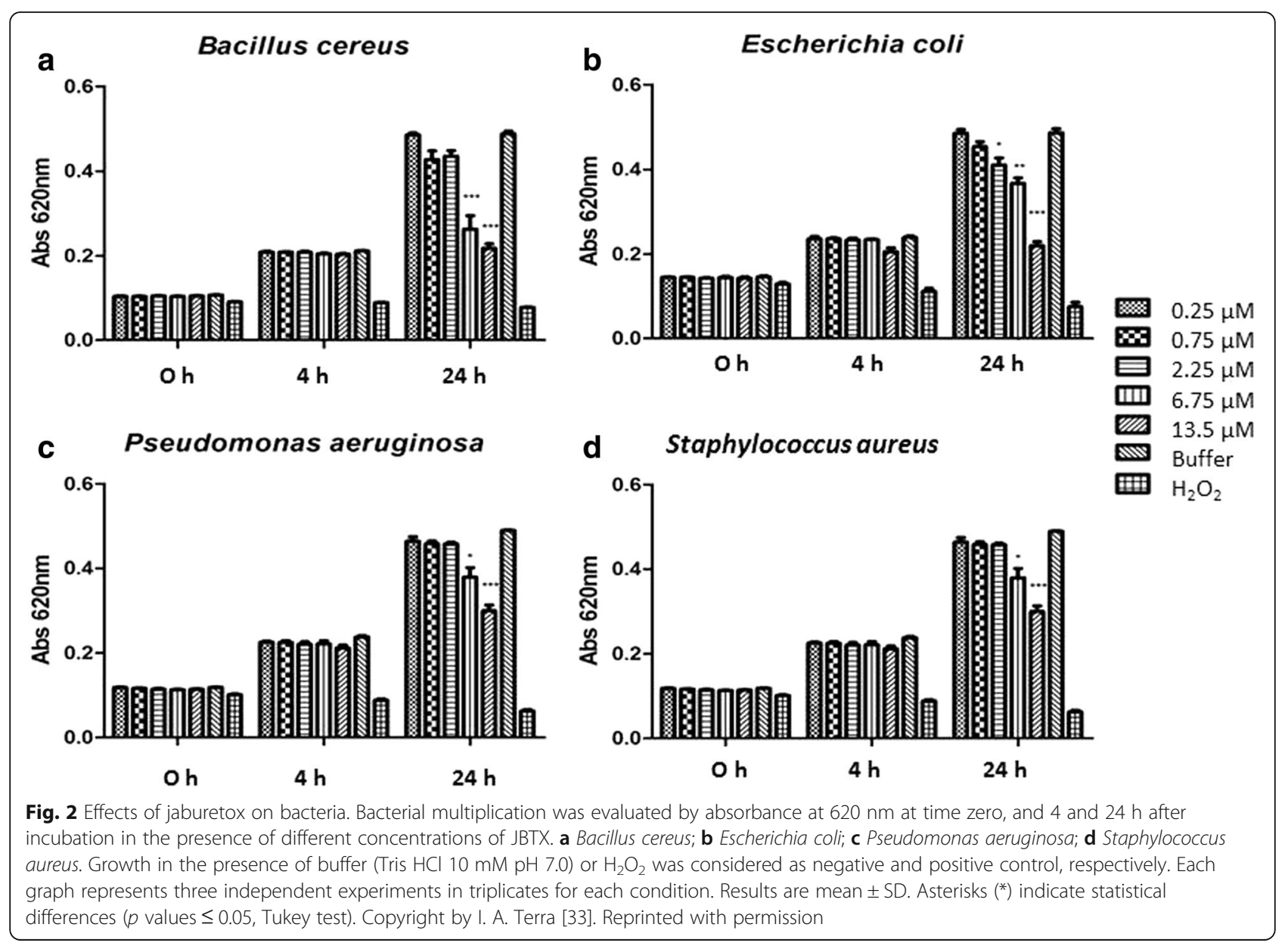

surface, we hypothesized that the JBTX-equivalent region of JBU drives the interaction of the protein with membranes [15]. The data revealed that indeed JBTX can insert itself into a lipid bilayer, eventually traversing the membrane, thereby disrupting the multilamellar structure of the liposomes [39]. There is no data so far to explain why or how JBTX can be selective towards pathogens or pests, while sparing host cells. In fact, JBTX has proved not to be cytotoxic against a panel of mammal tumoral cells at concentrations in the micromolar range (Portugal et al., unpublished data).

\section{Are JBTX-expressing transgenic plants more resistant to insect pests?}

With the exponential growth of the world population and the accompanying need for increasing food production, the advance of agriculture implies the creation of new insect control technologies that protect plants both during their development and at post-harvest (storage). The promise of transgenic crops expressing insecticidal polypeptides that dates back from the 1970s is now becoming true [40]. Corn plants producing Cry proteins derived from Bacillus thuringiensis (Bt) soil bacterium are produced since the early 1990s [41]. It is estimated that around 60 million hectares of Bt maize are grown globally and of these, 13 million hectares are cultivated in Brazil alone [42]. However, because insect resistance to the present Bt-expressing crops rapidly evolves, there is an urgent need to find new insecticidal polypeptides for the next generation of pest resistant transgenic plants to be used alone or in "stacking" strategies.

Preliminary biosafety studies showed that high doses of JBTX are innocuous to mice and rats, administered either orally or via injection. This finding encouraged studies on how to develop insect-resistant transgenic plants by heterologous expression of JBTX. A first attempt was conducted by Mulinari in 2008 [43], in which the peptide was inserted into the genome of tobacco SR1 plants by using a binary vector pCAMBIA2300-AMV-35Sd-jaburetox2-Tnos through Agrobacterium transformation. Young leaves of different transgenic tobacco plants expressing different levels of JBTX (as measured by ELISA) were then offered to Spodoptera frugiperda larvae. While leaves of some plants induced 50\% lethality of caterpillars (20 larvae per condition - plants with different amount of JBTX) after 30 days, other plants killed $100 \%$ of the larvae after 15 days [43]. 
Table 1 Antimicrobial activity of some peptide classes

\begin{tabular}{|c|c|c|c|c|}
\hline AMP class & AMP name & Plant species & Antimicrobial activity & Reference \\
\hline Defensin & Cp-thionin-2 & Vigna unguiculata & $\begin{array}{l}\text { Staphylococcus aureus }\left(128 \mu \mathrm{g} \cdot \mathrm{mL}^{-1}\right) \\
\text { Escherichia coli }\left(64 \mu \mathrm{g} \cdot \mathrm{mL}^{-1}\right)\end{array}$ & [36] \\
\hline Defensin & Fabatin-1 & Vicia faba & $\begin{array}{l}\text { E. coli }\left(100 \mu \mathrm{g} \cdot \mathrm{mL}^{-1}\right) \\
\text { Pseudomonas aeruginosa }\left(30 \mu \mathrm{g} \cdot \mathrm{mL}^{-1}\right)\end{array}$ & [35] \\
\hline Defensin & Fabatin-2 & V. faba & $\begin{array}{l}\text { E. coli }\left(100 \mu \mathrm{g} \cdot \mathrm{mL}^{-1}\right) \\
\text { P. aeruginosa }\left(30 \mu \mathrm{g} \cdot \mathrm{mL}^{-1}\right)\end{array}$ & [35] \\
\hline Defensin & StPTH1 & Solanum tuberosum cv Jaerla & $\begin{array}{l}\text { Clavibacter michiganensis }(7 \mu \mathrm{M}) \\
\text { Ralstonia solanacearum }(25 \mu \mathrm{M}) \\
\text { R. solanacearum }(r f a)(25 \mu \mathrm{M}) \\
\mathrm{EC}_{50} \text { - Effective concentration for } 50 \% \text { inhibition }\end{array}$ & [44] \\
\hline Defensin & Cn-AMP1 & Cocos nucifera & $\begin{array}{l}\text { Bacillus subtilis }\left(76 \mu \mathrm{g} \cdot \mathrm{mL}^{-1}\right) \\
\text { S. aureus }\left(80 \mu \mathrm{g} \cdot \mathrm{mL}^{-1}\right) \\
\text { E. coli }\left(82 \mu \mathrm{g} \cdot \mathrm{mL}^{-1}\right) \\
\text { P. aeruginosa }\left(79 \mu \mathrm{g} \cdot \mathrm{mL}^{-1}\right)\end{array}$ & [45] \\
\hline Defensin & Cn-AMP2 & C. nucifera & $\begin{array}{l}\text { B. subtilis }\left(150 \mu \mathrm{g} \cdot \mathrm{mL}^{-1}\right) \\
\text { S. aureus }\left(170 \mu \mathrm{g} \cdot \mathrm{mL}^{-1}\right) \\
\text { E. coli }(170 \mu \mathrm{g} / \mathrm{mL}) \\
\text { P. aeruginosa }\left(169 \mu \mathrm{g} \cdot \mathrm{mL}^{-1}\right)\end{array}$ & [45] \\
\hline Defensin & Cn-AMP3 & C. nucifera & $\begin{array}{l}\text { B. subtilis }\left(257 \mu \mathrm{g} \cdot \mathrm{mL}^{-1}\right) \\
\text { S. aureus }(274 \mu \mathrm{g} / \mathrm{mL}) ; \\
\text { E. coli }\left(302 \mu \mathrm{g} \cdot \mathrm{mL}^{-1}\right) \\
\text { P. aeruginosa }\left(259 \mu \mathrm{g} \cdot \mathrm{mL}^{-1}\right)\end{array}$ & {$[45]$} \\
\hline Cyclotide & Kalata B1 & Oldenlandia affinis (Roem. \& Schuld.) DC. & $\begin{array}{l}\text { S. aureus }\left(0.75 \mu \mathrm{g} \cdot \mathrm{mL}^{-1}\right) \text { and } \\
\text { Klebsiella oxytoca }\left(158.37 \mu \mathrm{g} \cdot \mathrm{mL}^{-1}\right)\end{array}$ & [46] \\
\hline Cyclotide & Circulin A & Collinsia parvifolia Schum. & $\begin{array}{l}\text { S. aureus }\left(0.59 \mu \mathrm{g} \cdot \mathrm{mL}^{-1}\right) \text { and } \\
\text { Proteus vulgaris }\left(172.04 \mu \mathrm{g} \cdot \mathrm{mL}^{-1}\right)\end{array}$ & [46] \\
\hline Cyclotide & Circulin B & C. parvifolia Schum. & $\begin{array}{l}\text { S. aureus }\left(44.32 \mu \mathrm{g} \cdot \mathrm{mL}^{-1}\right) \text {, } \\
\text { E. coli }\left(1.35 \mu \mathrm{g} \cdot \mathrm{mL}^{-1}\right) \text {, } \\
\text { P. aeruginosa }\left(83.7 \mu \mathrm{g} \cdot \mathrm{mL}^{-1}\right) \text {, } \\
\text { P. vulgaris }\left(22.3 \mu \mathrm{g} \cdot \mathrm{mL}^{-1}\right) \text { and } \\
\text { K. oxytoca }\left(26.92 \mu \mathrm{g} \cdot \mathrm{mL}^{-1}\right)\end{array}$ & [46] \\
\hline Cyclotide & Cycloviolacin $\mathrm{O} 2$ & Viola odorata & $\begin{array}{l}\text { Salmonella enterica }\left(8.75 \mu \mathrm{g} \cdot \mathrm{mL}^{-1}\right) \\
\text { E. coli }\left(2.2 \mu \mathrm{g} \cdot \mathrm{mL}^{-1}\right) \\
\text { S. aureus }\left(>50 \mu \mathrm{g} \cdot \mathrm{mL}^{-1}\right)\end{array}$ & [47] \\
\hline$\alpha / \beta$-Thionin & Alpha-1-purothionin & Triticum aestivum & $\begin{array}{l}\text { Pseudomonas solanacearum }\left(5 \mu \mathrm{g} \cdot \mathrm{mL}^{-1}\right) \\
\text { Xanthomonas phaseoli }\left(27 \mathrm{\mu g} \cdot \mathrm{mL}^{-1}\right) \\
\text { Xanthomonas campestres }\left(56 \mu \mathrm{g} \cdot \mathrm{mL}^{-1}\right) \\
\text { Erwinia amylovora }\left(540 \mathrm{\mu g} \cdot \mathrm{mL}^{-1}\right) \\
\text { Corynebacterium flaccumfaciens }\left(110 \mu \mathrm{g} \cdot \mathrm{mL}^{-1}\right) \\
\text { Clavibacter michiganense }\left(450 \mu \mathrm{g} \cdot \mathrm{mL}^{-1}\right) \\
\text { Corynebacterium poinsettiae }\left(56 \mu \mathrm{g} \cdot \mathrm{mL}^{-1}\right) \\
\text { Corynebacterium sepedonicun }\left(1 \mu \mathrm{g} \cdot \mathrm{mL}^{-1}\right)\end{array}$ & [48] \\
\hline$\alpha / \beta$-Thionin & PR-13 thionins & Nicotiana attenuate & Pseudomonas syringae $\mathrm{pv}$. Tomato $\left(0.25 \mu \mathrm{g} \cdot \mathrm{mL}^{-1}\right)$ & [49] \\
\hline Snakin & Snakin-1 & S. tuberosum & Listeria monocytogenes $\left(10 \mu \mathrm{g} \cdot \mathrm{mL}^{-1}\right)$ & {$[50]$} \\
\hline Snakin & StSN1 & S. tuberosum cv Jaerla & $\begin{array}{l}\text { C. michiganensis }(4 \mu \mathrm{M}) \\
\text { R. solanacearum }(r f a-)(15 \mu \mathrm{M}) \\
\mathrm{EC}_{50}-\text { Effective concentration for } 50 \% \text { inhibition }\end{array}$ & {$[44,51]$} \\
\hline Snakin & StSN2 & S. tuberosum cv Jaerla & $\begin{array}{l}\text { Clavibacter michiganensis }(1 \mu \mathrm{M}) \\
\text { R. solanacearum }(\mathrm{rfa}-)(30 \mu \mathrm{M}) \\
\text { Rhizobium meliloti }(8 \mu \mathrm{M}) \\
\mathrm{EC}_{50} \text { - Effective concentration for } 50 \% \text { inhibition }\end{array}$ & {$[44,51]$} \\
\hline LTP & LTP-s1 LTP-s2 & Spinacia oleracea & C. michiganensis subsp. Sepedonicus $\left(100 \mu \mathrm{g} \cdot \mathrm{mL}^{-1}\right)$ & [51] \\
\hline
\end{tabular}

In preliminary studies, transgenic sugarcane plants (cultivar SP803280) expressing the JBTX peptide under the $35 \mathrm{~S}$ promoter were obtained by callus bombardment. About 22 PCR-positive clones were generated and after regeneration, the transgenic sugarcane plants expressing JBTX ( 0.35 to $0.65 \mu \mathrm{g}$ per $\mathrm{mg}$ of total protein, quantified by ELISA) are now being screened for insect resistance. When challenged with Diatraea saccharalis, the stem 
borer, several of these plants proved to be more resistant to the caterpillar attack and in some cases caterpillar mortality reached 100\% (Becker-Ritt et al., unpublished data). The JBTX-expressing plants were also tested for resistance against the giant borer, Telchin licus licus, a relevant pest of sugarcane crops in some parts of Brazil. The young caterpillar feeds initially on the leaves of sugarcane and then penetrates through the soft parts of the stem (sheath). In some cases, when transgenic sugarcane plants expressing JBTX were exposed to giant borer larvae, $100 \%$ lethality of caterpillars was observed (Becker-Ritt et al, unpublished).

\section{Thinking about the future}

While diseases transmitted by $A$. aegypti continue to cause many deaths and insect pests damage livestock and agricultural production, there will be room for research on new and promising insecticidal agents such as JBTX. Not to mention the potent antifungal and bactericidal properties of this urease-derived polypeptide. However, many questions remain and should be clarified before any potential use of JBTX can be devised.

The mechanism of action of JBTX should be better understood. Is the ability of the peptide to interact with lipids what drives its interaction with cells or is there a "receptor" for the peptide in insect membranes? What happens with the intrinsically disordered regions of the peptide when it interacts with biological membranes? Does it acquire a more ordered biologically active structure or is its disordered nature required for its effects? How exactly does JBTX exert its neurotoxic effects or its immunomodulatory action? How specific is JBTX towards insects? Would the biosafety profile of JBTX allow the continuation of studies with insect resistant transgenic plants? Can nanoparticle technologies applied to JBTX, which aim at a controlled and efficient delivery of the entomotoxic peptide to its targets, provide novel solutions to overcome insect resistance, protect the environment and improve crop production? These are only a few questions awaiting to be answered. Meanwhile, although putting all our efforts to unravel the mysteries of JBTX, we still feel mesmerized on the wonders of this beautiful and versatile molecule.

\section{Conclusions}

Our goal with this article was to briefly review the biological activities performed by a recombinant peptide obtained from the Canavalia ensiformis urease sequence. The idea was to demonstrate that this recombinant peptide is capable of exerting inhibitory activity on fungi, yeasts, bacteria and insects, and similarly to other plant ureases, JBTX is also capable of acting on plant defense. In addition, the peptide is effective in inhibiting bacteria of medical and agronomic interest and is capable of causing lethality in insect pests of sugarcane, tobacco and corn. In spite of these biological activities, the peptide is innocuous to mammals and non-target organisms and can be used both in the development of transgenic plants resistant to diseases and pests and in the formulation of bioinsecticides.

\begin{abstract}
Abbreviations
AMPs: Antimicrobial peptides; Bt: Bacillus thuringiensis; CNS: Central nervous system; CNTX: Canatoxin; $\mathrm{H}_{2} \mathrm{O}_{2}$ : Hydrogen peroxide; Jaburetox- $\Delta \beta$ : Jaburetox without the amino acids 61 to 74; JBTX: Jaburetox; JBTX C-ter: Jaburetox Cterminal; JBTX N-ter: Jaburetox N-terminal; JBU: Jack bean urease; PLB: Planar lipid bilayers; SAXS: Small angle X-ray scattering; UDP-GICNACP: UDP-Nacetylglucosamine pyrophosphorylase
\end{abstract}

\section{Acknowledgments}

The authors would like to thank ULBRA, PUCRS, CAPES and CNPq for their support. Thanks are also due to the Center for the Study of Venoms and Venomous Animals (CEVAP) of UNESP for enabling the publication of this paper (Edital Toxinologia CAPES no. 063/2010, Process no. 230.38.006285/ 2011-21, AUXPE Toxinologia 1219/2011).

\section{Funding}

The present study was supported by the Coordination for the Improvement of Higher Education Personnel (CAPES) through the Toxicology Program 63/2010, process 1205/2011; and the National Council for Scientific and Technological Development (CNPq) through the universal program, processes 475908/2012-0 and 446052/2014-1.

\section{Authors' contributions}

All authors participated in writing and revising the manuscript. Moreover, all authors read and approved the final manuscript.

\section{Competing interests}

The authors declare that they have no competing interests.

\section{Consent for publication}

Not applicable.

Ethics approval and consent to participate Not applicable.

\section{Publisher's Note}

Springer Nature remains neutral with regard to jurisdictional claims in published maps and institutional affiliations.

\section{Author details}

${ }^{1}$ Graduate Program in Cellular and Molecular Biology Applied to Health, Lutheran University of Brazil (ULBRA), Canoas, RS, Brazil. " Brain Institute (Instituto do Cérebro-INSCER), Pontifical Catholic University of Rio Grande do Sul (PUCRS), Porto Alegre, RS, Brazil.

Received: 23 December 2016 Accepted: 6 June 2017

Published online: 15 June 2017

\section{References}

1. Carter EL, Flugga N, Boer JL, Mulrooney SB, Hausinger RP. Interplay of metal ions and urease. Metallomics. 2009;1(3):207-21.

2. Krajewska B, Ureases I. Functional, catalytic and kinetic properties: a review. J Mol Catal B Enzym. 2009;59(1-3):9-21.

3. Sumner JB. The isolation and crystallization of the enzyme urease: preliminary paper. J Biol Chem. 1926;69:435-41.

4. Dixon NE, Gazzola C, Watters JJ, Blakely RL, Zerner B. Inhibition of Jack Bean urease (EC 3.5.1.5) by acetohydroxamic acid and by phosphoramidate. An equivalent weight for urease. J Am Chem Soc. 1975;97(14):4130-1.

5. Zerner B. Recent advances in the chemistry of an old enzyme, urease. Bioorg Chem. 1991;19(1):116-31.

6. Follmer C, Barcellos GB, Zingali RB, Machado OL, Alves EW, Barja-Fidalgo C, et al. Canatoxin, a toxic protein from jack beans (Canavalia ensiformis), is a 
variant form of urease (EC 3.5.1.5): biological effects of urease independent of its ureolytic activity. Biochem J. 2001;360(Pt 1):217-24.

7. Carlini $C R$, Guimarães JA. Isolation and characterization of a toxic protein from Canavalia ensiformis (jack bean) seeds, distinct from concanavalin A. Toxicon. 1981;19(5):667-76

8. Follmer C, Carlini CR, Yoneama ML, Dias JF. PIXE analysis of urease isoenzymes isolated from Canavalia ensiformis (jack bean) seeds. Nucl Instrum Methods Phys Res B. 2002;189(1-4):482-6.

9. Becker-Ritt AB, Carlini CR. Fungitoxic and insecticidal plant polypeptides. Biopolymers. 2012;98(4):367-84

10. Mulinari F, Stanisçuaski F, Bertholdo-Vargas LR, Postal M, Oliveira-Neto $\mathrm{OB}$, Rigden DJ, et al. Jaburetox-2Ec: an insecticidal peptide derived from an isoform of urease from the plant Canavalia ensiformis. Peptides. 2007;28(10):2042-50

11. Postal M, Martinelli AH, Becker-Ritt AB, Ligabue-Braun R, Demartini DR, Ribeiro SF, et al. Antifungal properties of Canavalia ensiformis and derived peptides. Peptides. 2012;38(1):22-32.

12. Carlini CR, Ligabue-Braun R. Ureases as multifunctional toxic proteins: a review. Toxicon. 2016;110:90-109.

13. Stanisçuaski F, Te Brugge V, Carlini CR, Orchard I. In vitro effect of Canavalia ensiformis urease and the derived peptide Jaburetox-2Ec on Rhodnius prolixus Malpighian tubules. J Insect Physiol. 2009;55(3):255-63.

14. Martinelli AH, Kappaun K, Ligabue-Braun L, Defferrari MS, Piovesan AR, Stanisçuaski F, et al. Structure-function studies on Jaburetox, a recombinant insecticidal peptide derived from jack bean (Canavalia ensiformis) urease. Biochim Biophys Acta. 2014;1840(3):935-44.

15. Piovesan AR, Martinelli AHS, Ligabue-Braun R, Schwartz JL, Carlini CR. Canavalia ensiformis urease, Jaburetox and derived peptides form ion channels in planar lipid bilayers. Arch Biochem Biophys. 2014;547:6-17.

16. Lopes FC, Dobrovolska O, Real-Guerra R, Broll V, Zambelli B, Musiani F, et al. Pliable natural biocide: Jaburetox is an intrinsically disordered insecticidal and fungicidal polypeptide derived from jack bean urease. FEBS J. 2015; 282(6):1043-64.

17. Zara ALSA, Santos SM, Fernandes-Oliveira ES, Carvalho RG, Coelho GE. Estratégias de controle do Aedes aegypti: Uma revisão. Epidemiol Serv Saúde. 2016:25(2):391-404.

18. Nunes $M L$, Carlini CR, Marinowic D, Neto FK, Fiori HH, Scotta MC, et al. Microcephaly and Zika virus: a clinical and epidemiological analysis of the current outbreak in Brazil. J Pediatr (Rio J). 2016;92(3):230-40.

19. Kappaun K. Estudos com o Jaburetox: efeito tóxico de E. coli liofilizadas carregadas com o peptídeo e análise da influência do epitopo v5 na formação de agregados. Trabalho de conclusão de curso, Faculdade de Farmácia, Universidade Federal do Rio Grande do Sul. 2011. http://www. lume.ufrgs.br/handle/10183/70125. Accessed 22 May 2017.

20. Lardeux F, Depickère S, Aliaga C, Chavez T, Zambrana L. Experimental control of Tiatoma infestans in poor rural villages of Bolivia through community participation. Trans R Soc Trop Med Hyg. 2015;109(2):150-8.

21. Dias JCP, Silveira AC, Schofield CJ. The impact of Chagas disease control in Latin America: a review. Mem Inst Oswaldo Cruz. 2002;97(5):603-12.

22. Galvani GL, Fruttero LL, Coronel MF, Nowicki S, Demartini DR, Defferrari MS, et al. Effect of the urease-derived peptide Jaburetox on the central nervous system of Triatoma infestans (Insecta: Heteroptera). Biochim Biophys Acta. 2015:1850(2):255-62

23. Stanisçuaski F, Ferreira-Dasilva CT, Mulinari F, Pires-Alves $M$, Carlini CR. Insecticidal effects of canatoxin on the cotton stainer bug Dysdercus peruvianus (Hemiptera: Pyrrhocoridae). Toxicon. 2005;45(6):753-60.

24. Fruttero LL, Moyetta NR, Uberti AF, Grahl MVC, Lopes FC, Broll V, et al. Humoral and cellular immune responses induced by the urease-derived peptide Jaburetox in the model organism Rhodnius prolixus. Parasit Vectors. 2016;9:412.

25. ONU Brasil. Brasil e países africanos debatem proteção social em fórum na África do Sul. https://nacoesunidas.org/brasil-e-paises-africanos-debatemprotecao-social-em-forum-na-africa-do-sul/. Accessed 21 Nov 2016.

26. 2016 World Hunger and Poverty Facts and Statistics. http://www. worldhunger.org/2015-world-hunger-and-poverty-facts-and-statistics/. Accessed 06 Apr 2017.

27. Popp J, Pető K, Nagy J. Pesticide productivity and food security. A review. Agron Sustain Dev. 2013:33:243-55.

28. Sugayama RL, da Silva ML, Silva SXB, Ribeiro LC, Rangel LEP. Defesa vegetal: fundamentos, ferramentas, políticas e perspectivas. 2015. http://www. defesaagropecuaria.net/livrodefesavegetal.
29. Companhia Nacional de Abastecimento (Conab). Acompanhamento da safra brasileira de cana-de-açúcar, v. 3, safra 2016/17, n. 3. Brasília: Conab; 2016. ISSN 2318-7921. http://www.conab.gov.br/OlalaCMS/uploads/arquivos/ 16_12_27_16_30_01_boletim_cana_portugues_-30_lev_-_16-17.pdf. Accessed 30 May 2017

30. Pomari-Fernandes A, Bueno AF, Sosa-Gómez DR. Helicoverpa armigera: current status and future perspectives in Brazil. Curr Agri Sci Tech. 2015;21(1):1-7.

31. Terra IA, Portugal CS, Becker-Ritt AB. Plant antimicrobial peptides. In: Méndez-Vilas A, editor. The battle against microbial pathogens: Basic Science, technological advances and educational programs. Spain: Formatex; 2015. p. 199-207.

32. Pompilio A, Scocchi M, Pomponio S, Guida F, Di Primio A, Fiscarelli E, et al. Antibacterial and anti-biofilm effects of cathelicidin peptides against pathogens isolated from cystic fibrosis patients. Peptides. 2011;32(9):1807-14

33. Terra IA. Avaliação da atividade antibacteriana do peptídeo jaburetox. Doctoral thesis. Programa de Pós-Graduação em Biologia Celuar e Molecular Aplicada à Saúde, Universidade Luterana do Brasil. 2016. https://sucupira. capes.gov.br/sucupira/public/consultas/coleta/trabalhoConclusao/ viewTrabalhoConclusao.jsf?popup=true\&id_trabalho=3725605. Accessed 10 June 2017.

34. Zhang Y, Lewis K. Fabatins: new antimicrobial plant peptides. FEMS Microbiol Lett. 1997;149(1):59-64.

35. Carvalho Ade O, Gomes VM. Plant defensins-prospects for the biological functions and biotechnological properties. Peptides. 2009:30(5):1007-20.

36. Franco OL, Murad AM, Leite JR, Mendes PAM, Prates MV, Bloch Jr C. Identification of a cowpea gamma-thionin with bactericidal activity. FEBS J. 2006;273(15):3489-97.

37. Sharma S, Verma HN, Sharma NK. Cationic Bioactive Peptide from the Seeds of Benincasa hispida. Int J Pept. 2014;2014. doi: 10.1155/156060.

38. Barros PR, Stassen $H$, Freitas MS, Carlini CR, Nascimento MA, Follmer C. Membrane-disruptive properties of the bioinsecticide Jaburetox-2Ec: implications to the mechanism of the action of insecticidal peptides derived from ureases. Biochim Biophys Acta. 2009:1794(12):1848-54.

39. Micheletto YMS, Moro CF, Lopes FC, Ligabue-Braun R, Martinelli AHS, Marques CM, et al. Interaction of jack bean (Canavalia ensiformis) urease and derived peptide with lipid vesicles. Colloids Surf B: Biointerfaces. 2016;145:576-85.

40. Carlini CR, Grossi-De-Sá MF. Plant toxic proteins with insecticidal properties. A review on their potentialities as bioinsecticides. Toxicon. 2002:40(11):1515-39.

41. Hellmich RL, Hellmich KA. Use and impact of Bt maize. Nat Educ Know. 2012;3(10):4

42. ISAAA. Global Status of Commercialized Biotech/GM Crops: 2016. ISAAA Brief no. 52. Ithaca, NY: ISAAA; 2016. https:/www.isaaa.org/resources/publications/ briefs/52/download/isaaa-brief-52-2016.pdf. Accessed 30 May 2017.

43. Mulinari F. Ureases de Canavalia ensiformis e peptídeo inseticida derivado. Tese de doutorado. Centro de Biotecnologia, Universidade Federal do Rio Grande do Sul. 2008. http://www.lume.ufrgs.br/handle/10183/13944. Accessed 10 June 2017.

44. Berrocal-Lobo M, Segura A, Moreno M, López G, García-Olmedo F, Molina A. Snakin-2, an antimicrobial peptide from potato whose gene is locally induced by wounding and responds to phatogen infection. Plant Physiol. 2002;128(3):951-61.

45. Mandal SM, Dey S, Mandal M, Sarkar S, Maria-Neto S, Franco OL. Identification and structural insights of three novel antimicrobial peptides isolated from green coconut water. Peptides. 2009;30(4):633-7.

46. Gruber CW. Global cyclotide adventure: a journey dedicated to the discovery of circular peptides from flowering plants. Biopolymers. 2010;94(5):565-72.

47. Pränting M, Lööv C, Burman R, Göransson ULF, Andersson DI. The cyclotide cycloviolacin $\mathrm{O} 2$ from Viola odorata has potent bactericidal activity against Gram-negative bacteria. J Antimicrob Chemother. 2010;65(9):1964-71.

48. Fernandez de Caleya R, Gonzalez-Pascual B, García-Olmedo F, Carbonero P. Susceptibility of phytopathogenic bacteria to wheat purothionins in vitro. Appl Microbiol. 1972;23(5):998-1000.

49. Rayapuram C, Wu J, Haas C, Baldwin IT. PR-13/Thionin but not PR-1 mediates bacterial resistance in Nicotiana attenuata in nature, and neither influences herbivore resistance. Mol Plant Microbe Interact. 2008;21(7):988-1000.

50. Yount NY, Yeaman MR. Multidimensional signatures in antimicrobial peptides. Proc Natl Acad Sci U S A. 2004:101(19):7363-8.

51. Segura A, Moreno M, Madueño F, Molina A, García-Olmedo F. Snakin-1, a peptide from potato that is active against plant pathogens. Mol Plant Microbe Interact. 1999;12(1):16-23. 